\title{
Role of TLR1, TLR2 and TLR6 in the modulation of intestinal inflammation and Candida albicans elimination
}

\author{
Laura Choteau 1,2,3, Hélène Vancraeyneste ${ }^{1,2,3}$, Didier Le Roy ${ }^{4}$, Laurent Dubuquoy ${ }^{1,2}$, Luiginia Romani ${ }^{5}$, \\ Thierry Jouault ${ }^{1,2}$, Daniel Poulain ${ }^{1,2,3}$, Boualem Sendid ${ }^{1,2,3}$, Thierry Calandra ${ }^{4}$, Thierry Roger ${ }^{4}$ \\ and Samir Jawhara ${ }^{1,2,3^{*}}$
}

\begin{abstract}
Background: Toll-like receptors (TLRs) are the major pattern recognition receptors that mediate sensing of a wide range of microorganisms. TLR2 forms heterodimers with either TLR1 or TLR6, broadening its ligand diversity against pathogens. TLR1, TLR2 and TLR6 have been implicated in the recognition of Candida albicans, an opportunistic fungal pathogen that colonizes the gastrointestinal tract. In this study, we explored whether the deficiency in TLR1, TLR2 or TLR6 impacts C. albicans colonization and inflammation-associated colonic injury in the dextran sulfate sodium (DSS)induced colitis in mice.

Results: DSS treatment and C. albicans challenge induced greater weight loss, worse clinical signs of inflammation, higher histopathologic scores, and increased mortality rates in $\mathrm{TLR}^{-1-}$ and $\mathrm{TLR} 2^{-1-}$ mice when compared to $\mathrm{TLR}^{-1-}$ and wild-type mice. The number of $C$. albicans colonies in the stomach, colon and feces was decreased in TLR6 ${ }^{-1-}$ mice as compared to TLR2 ${ }^{-1-}, \mathrm{TLR}^{-/-}$and wild-type mice. Interestingly, the population of $E$. coli in colonic luminal contents, intestinal permeability to FITC-dextran and cytokine expression were significantly increased in TLR1 ${ }^{-/-}$and $\mathrm{TLR}^{-/-}$mice, while they were decreased in $\mathrm{TLR}^{-/-}$mice.

Conclusion: In contrast to TLR6, both TLR1 and TLR2 deficiencies increased intestinal inflammation, and the overgrowth of C. albicans and E. coli populations in the colitis model, suggesting the involvement of TLR1 and TLR2 in epithelial homeostasis, and a role of TLR6 in increasing intestinal inflammation in response to pathogen-sensing.
\end{abstract}

Keywords: TLR1, TLR2, TLR6, Candida albicans, E. coli, Colitis

\section{Background}

Toll-like receptors (TLRs) are the main family of pattern recognition receptors (PRRs) through which immune and non-immune cells sense pathogen-associated molecular patterns (PAMPs) [1, 2]. Several TLRs are implicated in the recognition of fungal pathogens such as Candida albicans [3, 4]. The interaction between TLRs and yeasts during candidiasis stimulates immune cells to generate inflammatory and immunomodulatory mediators that

*Correspondence: samir.jawhara-3@univ-lille2.fr

1 INSERM U995/2, Université Lille Nord de France, 1 Place Verdun,

59000 Lille, France

Full list of author information is available at the end of the article shape the host immune response. Unlike TLR4, TLR2 recognizes both blastoconidia and hyphal forms of $C$. albicans [5]. TLR2 forms heterodimers with either TLR1 or TLR6 which have been implicated in ligand discrimination [6]. TLR2 senses phospholipomannans, which are expressed in the cell wall of $C$. albicans [7]. In addition, TLR2 in combination with galectin-3 also senses $\beta$-mannosides [8].

TLRs are expressed not only in myeloid cells and leukocytes, but also in the intestinal epithelium, which contributes to mucosal homeostasis by preventing the penetration of commensal microbiota into the intestine $[9,10]$. In an animal model of colitis, TLR2 ${ }^{-1-}$ mice developed more severe colonic inflammation than 
wild-type mice [11]. Moreover, mutations in TLRs, including the TLR2 gene, have been associated with predisposition to and maintenance of inflammatory bowel disease (IBD) [12-14]. Interestingly, in patients with ulcerative colitis, Pierik et al. [15] observed an association between TLR1 and TLR2 gene polymorphisms and pancolitis, and a negative relationship between TLR6 polymorphisms and pancolitis, suggesting that TLR2 and its co-receptors TLR1 and TLR6 are involved in the initial immune response to pathogens in the development of IBD.

The aim of this study was to determine the impact of TLR1, TLR2, and TLR6 deficiency on inflammatory parameters associated with $C$. albicans colonization and acute colitis induced by DSS by comparing wildtype, TLR $1^{-1-}$, TLR2 $2^{-1-}$, and TLR6 ${ }^{-1-}$ mice. We also assessed intestinal permeability, serological response, and colonic expression levels of pro-inflammatory and anti-inflammatory cytokines in control and TLRdeficient mice. Finally, we explored the effects of TLR deficiency on neutrophil-mediated C. albicans phagocytosis/death.

\section{Results}

Candida albicans CFU in stools and mouse body weight $\mathrm{TLR}^{-1-}{ }^{-}$TLR2 ${ }^{-1-}$, $\mathrm{TLR}^{-1-}$, and wild-type mice were challenged with a single oral inoculum of $C$. albicans $\left(10^{7} \mathrm{CFU}\right)$ and the amount of yeast in stool samples was analyzed daily for 2 weeks to assess the colonization rate (Fig. 1a). C. albicans colonization was not observed in any of these mice a few days later. In the absence of DSS, no significant differences in body weight were observed between TLR deficient mice and wild-type mice that received C. albicans (Fig. 1b). Additionally, there were no differences between wild-type and TLR deficient mice that challenged with $C$. albicans in terms of clinical and histological scores (data not shown).

\section{Mouse weight and survival analysis in DSS-induced murine colitis}

To assess the association between TLR1, TLR 2 or TLR6 deficiency and C. albicans colonization in DSSinduced murine colitis, mice were monitored daily for 2 weeks for body weight loss and survival after a single oral challenge with C. albicans and DSS treatment (Fig. 2a). All mice treated with DSS showed significant body weight loss, and no mortality was observed. Interestingly, C. albicans colonization caused a greater body weight loss in TLR1 $1^{-/-}$and TLR2 $2^{-1-}$ DSS mice when compared to TLR6 ${ }^{-1-}$ and wild-type DSS-treated mice (Fig. 2b-d). From day 9, when compared to wildtype mice treated with $C$. albicans and DSS, there was a significant decrease in body weight of $\mathrm{TLR} 1^{-/-}$and

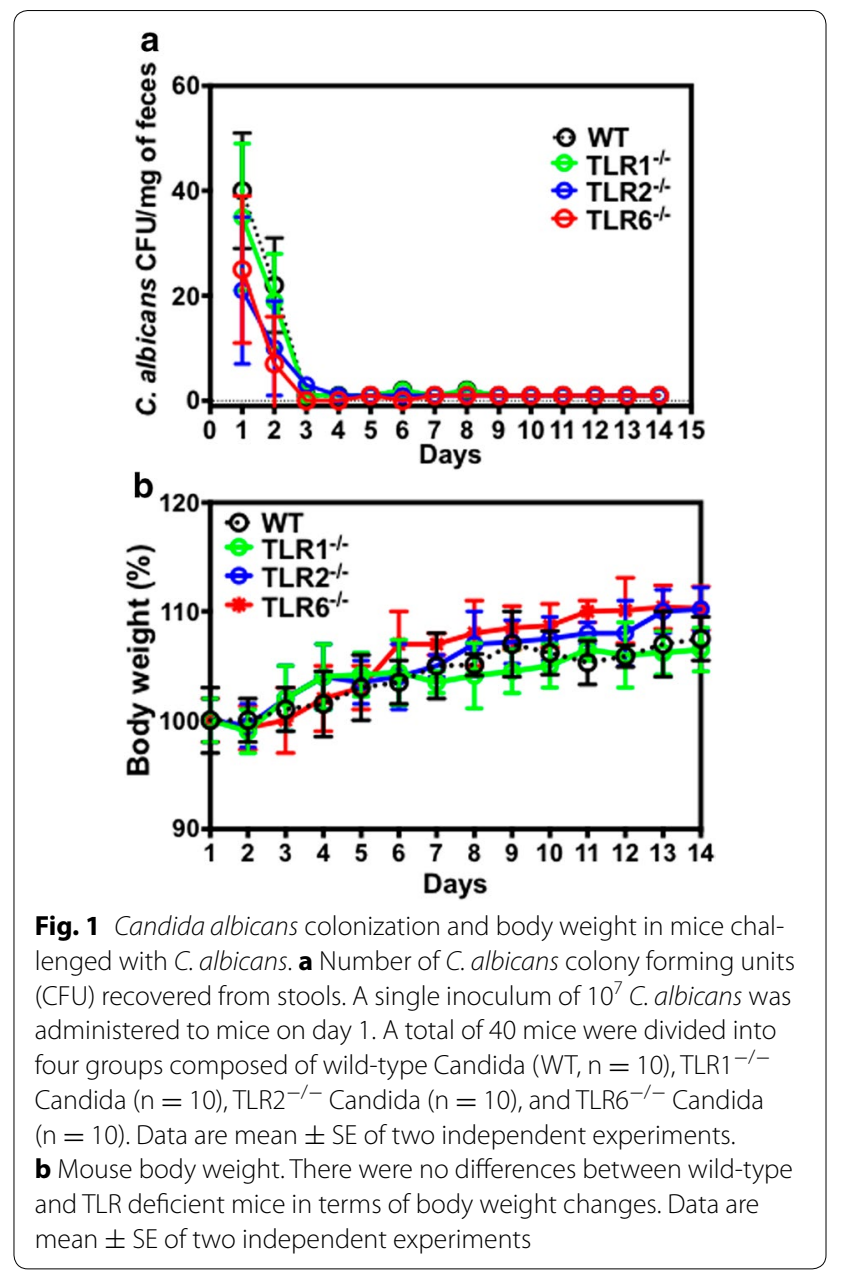

TLR2 ${ }^{-1-}$ mice treated with C. albicans and DSS. Furthermore, the C. albicans and DSS-treated mouse survival rate was lower in TLR1 $1^{-1-}$ and $\mathrm{TLR} 2^{-1-}$ mice (86\% survival) than in TLR6 $^{-1-}$ and wild-type mice (93\% survival) (Fig. 2e).

\section{Clinical and histologic inflammation scores}

To evaluate clinical inflammation scores, mice were monitored daily using the parameters of stool consistency and the presence or absence of faecal blood (Fig. 2f). In the absence of $C$. albicans challenge, no significant difference in clinical scores for inflammation was observed between DSS-treated $\mathrm{TLR}^{-1-}$ and DSS-treated wild-type mice. In contrast, clinical scores for inflammation were significantly higher in TLR $1^{-1-}$ and TLR2 ${ }^{-1-}$ mice than in wild-type DSS-treated mice. Importantly, the clinical symptoms of colitis, such as diarrhea and bloody stools, appeared more rapidly in $\mathrm{TLR}^{-1-}$ and $\mathrm{TLR}^{-1-}$ mice than in wild-type and TLR6 $^{-1-}$ C. albicans and DSS-treated mice. Microscopic inflammatory changes were also assessed in mice 
a

$\underbrace{\text { Oral administration of } C \text {. albicans }}_{\text {Day } 1}$

b

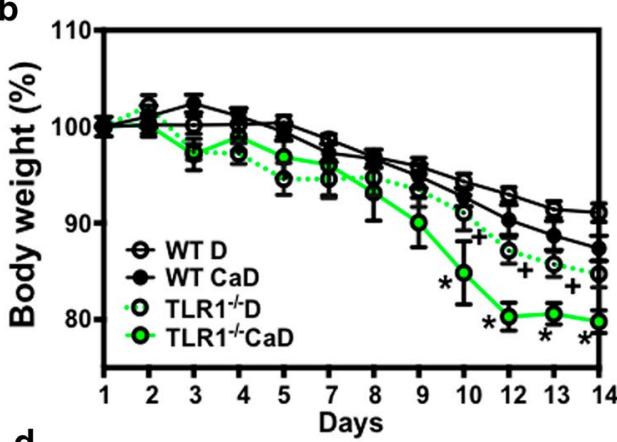

d

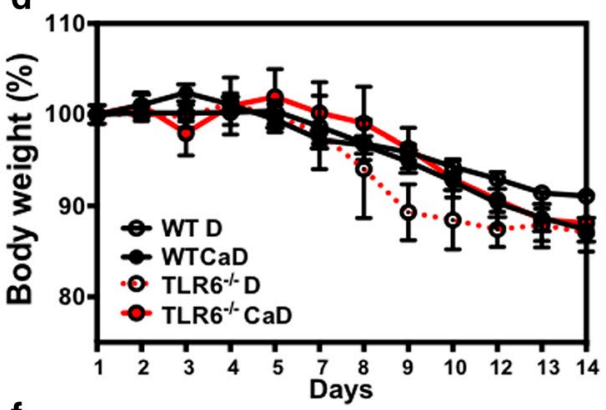

f

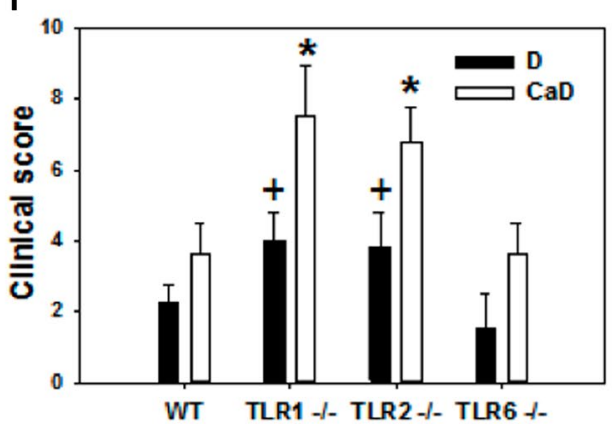

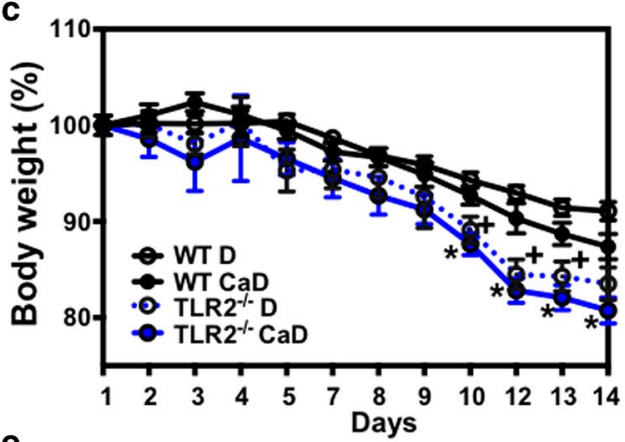

e
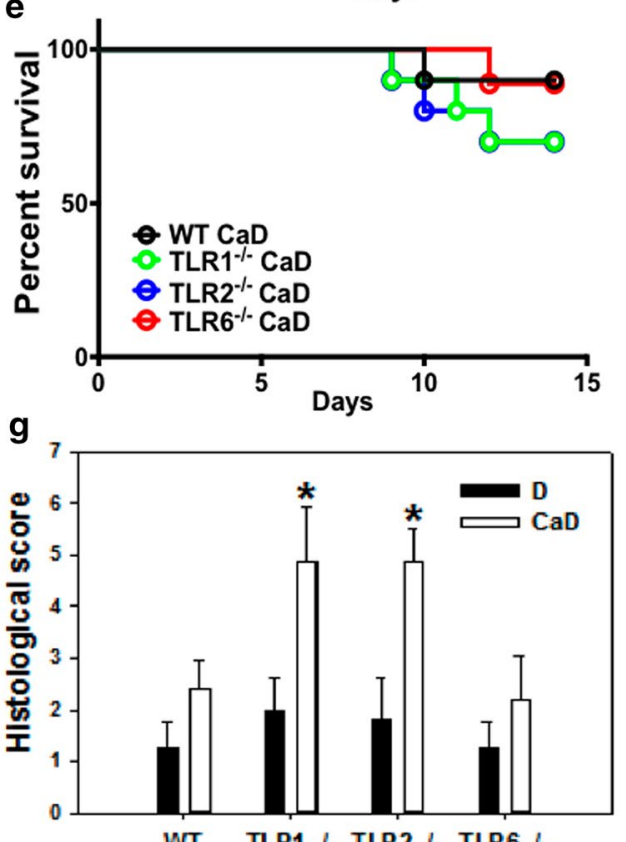

Fig. 2 Increased morbidity and mortality of TLR1 ${ }^{-1-}$ and TLR2 ${ }^{-1-}$ mice due to C. albicans and DSS-induced colitis. a Schematic representation of the experimental procedure. A single inoculum of $10^{7} \mathrm{C}$. albicans was administered to mice on day 1 and low doses of DSS (1.5\%) were given in the drinking water for 2 weeks. A total of 120 mice were divided into eight groups composed of wild-type DSS (WT D, $n=10)$, wild-type C. albicans and

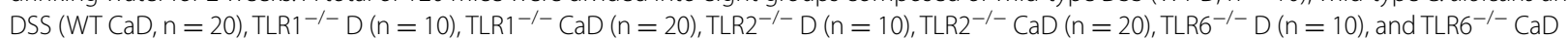
$(n=20)$ mice. b-d Mouse body weight. Data are the mean \pm SE of two independent experiments. ${ }^{+} P<0.05$ for TLR-deficient CaD mice versus wild-type $D$ mice. ${ }^{*} P<0.05$ for TLR-deficient CaD mice versus wild-type CaD mice. e Mouse survival. Results are expressed as percent survival from the time of C. albicans challenge and DSS treatment. The survival data were significantly different by the log-rank test $(P<0.05)$. $\mathbf{f}$ Clinical analysis of DSS-induced colitis in mice. Clinical score was determined by assessing weight loss, change in stool consistency and presence of gross bleeding. The clinical score ranged from 0 to 8 (each value corresponds to the mean value of 14 days per group). ${ }^{+} P<0.05$ for TLR1 ${ }^{-/-}$DSS (d) and TLR2 ${ }^{-/-} D$ mice versus wild-type (WT) D mice; and ${ }^{*} P<0.05$ for $\mathrm{TLR}^{-/-}$C. albicans and DSS (CaD) and TLR2 ${ }^{-/-}$CaD mice versus wild-type CaD mice. g Histologic scores. Mice were exposed to 1.5\% DSS in drinking water for 14 days. Scores range from 0 (no changes) to 6 (extensive cell infiltration and tissue damage). ${ }^{*} P<0.05$ for $\mathrm{TLR}^{-1-} \mathrm{CaD}$ and $\mathrm{TLR} 2^{-/-} \mathrm{CaD}$ mice versus wild-type CaD mice

colons (Fig. 2g). All surviving animals were sacrificed on day 14 and histologic injury scoring was performed on the colons. Histologic scores, based on the extent of infiltration of inflammatory cells and the degree of tissue damage, ranged from 0 to 6 , and reflected inflammation and crypt damage caused by DSS. No significant difference in the histologic score was detected between wild-type and TLR-deficient DSS-treated mice. In contrast, histologic scores were substantially higher in C. albicans and DSS-treated TLR $1^{-/-}$and 
TLR2 ${ }^{-1-}$ as compared to TLR6 ${ }^{-1-}$ and wild-type mice $(P<0.05)$. Epithelial damage occurred throughout the colonic mucosa, and the infiltrated cells were mostly polynuclear (Fig. 3). In addition, cryptic abscesses and mucosal edema was more frequently observed in the colons of TLR $1^{-/-}$and TLR2 $2^{-I-}$ mice than in those of TLR6 $^{-1-}$ and wild-type C. albicans and DSS-treated mice (Fig. 3).

\section{Effects of DSS-induced colitis on C. albicans colonization}

Mice were challenged with a single oral inoculum of C. albicans $\left(10^{7} \mathrm{CFU}\right)$ and given $1.5 \%$ DSS in drinking water for 14 days (Fig. 4a). Despite a trend towards higher number of C. albicans CFUs in the stools of TLR1 ${ }^{-1-}$ mice, there was no significant difference between wild-type, TLR $1^{-1-}$, and TLR2 ${ }^{-1-}$ mice during the entire observation period. In contrast, the number of $C$. albicans CFUs strongly decreased in the stools of $\mathrm{TLR6}^{-1-}$ mice on day 7 after challenge, and remained significantly lower than that of wild-type mice up to day $13(P<0.05)$.

To evaluate $C$. albicans colonization in the gut, the number of yeasts adhering to the stomach and colon was determined (Fig. 4b, c). Significantly higher numbers of CFUs were observed in the stomach of $\mathrm{TLR}^{-l-}$ mice when compared to TLR $2^{-/-}, \mathrm{TLR}^{-1-}$,

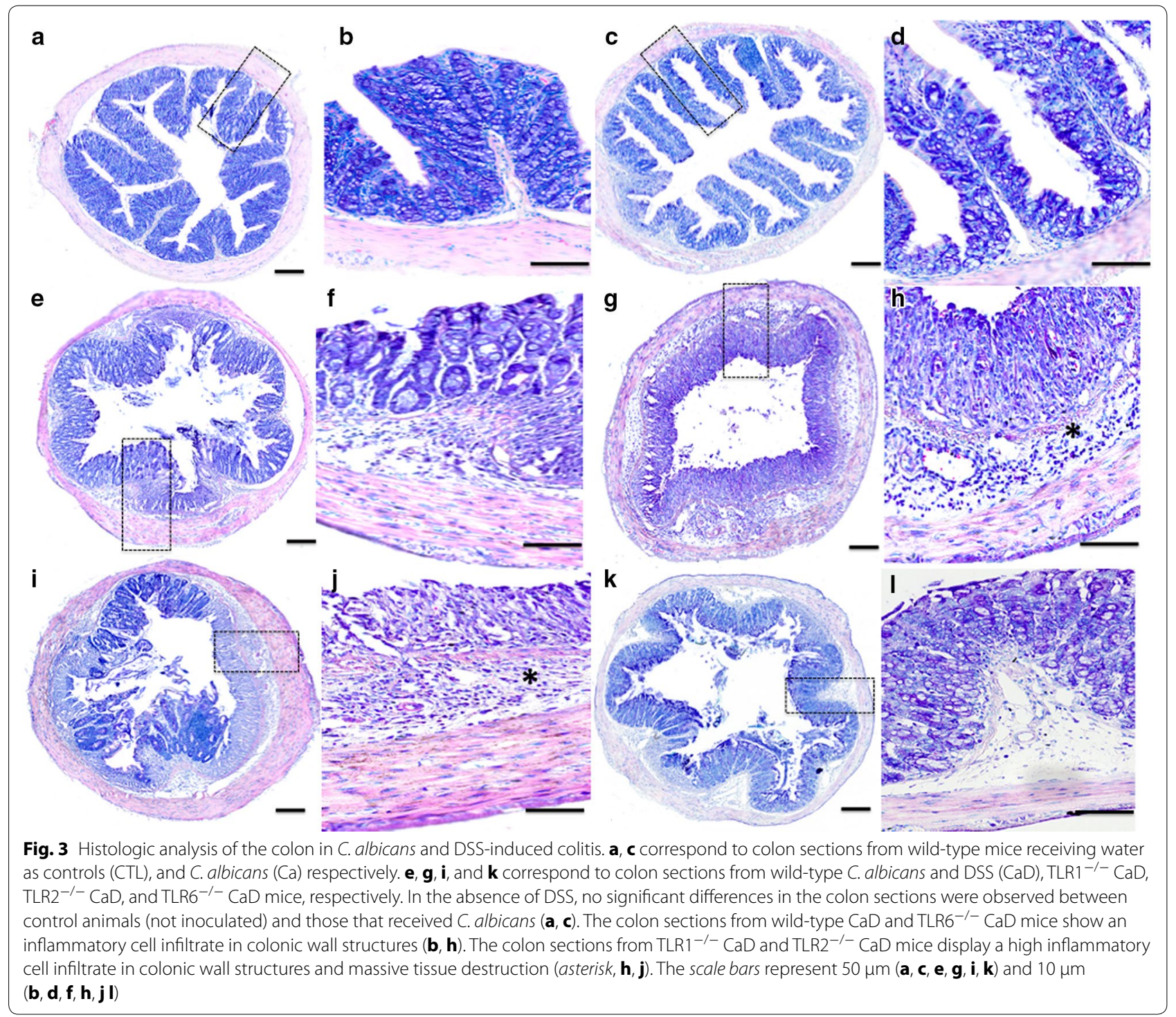




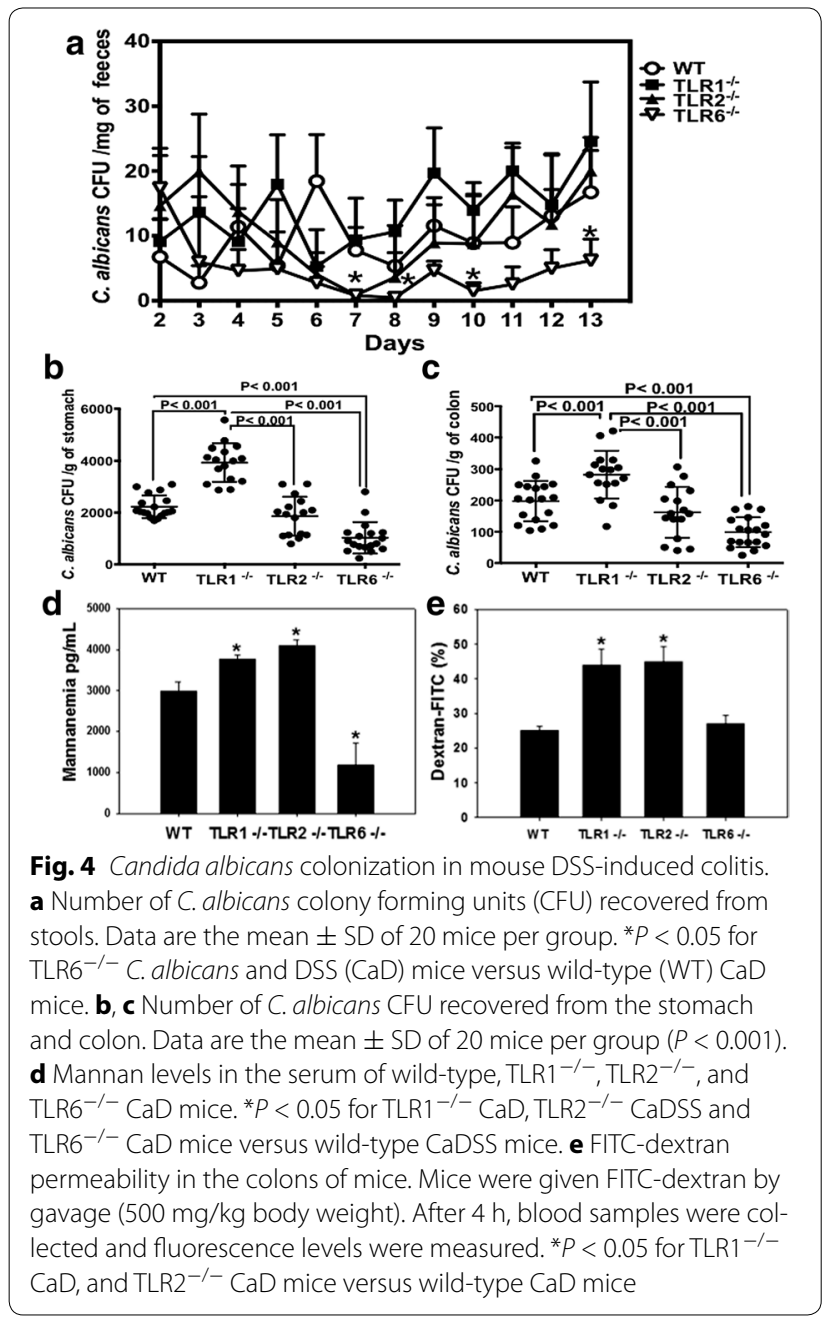

and wild-type mice $(P<0.001)$. C. albicans did not disseminate to the lungs, heart, liver, spleen or kidneys of wild-type and TLR deficient mice (data not shown).

\section{Serologic analysis and intestinal permeability}

To evaluate the association between anti-mannan antibody titers, $C$. albicans colonization, and TLR deficiency in DSS-treated mice, we assessed mannanemia, which correlates to mannan levels in the blood (Fig. 4d). Mannanemia was higher in TLR1 $1^{-1-}$ and TLR2 $^{-1-}$ mice as compared to wild-type $C$. albicans and DSS-treated mice $(P<0.05)$, which correlated with the higher clinical and histologic scores for inflammation in $\mathrm{TLR} 1^{-1-}$ and $\mathrm{TLR} 2^{-/-}$mice. Additionally, mannanemia was significantly lower in $\mathrm{TLR}^{-1-}$ than that of wild-type mice $(P<0.05)$. Next, we assessed the in vivo intestinal permeability using fluorescein isothiocyanate (FITC)-dextran (Fig. 4e). Intestinal permeability of FITC-dextran was significantly increased in $\mathrm{TLR} 1^{-1-}$ and $\mathrm{TLR} 2^{-/-}$as compared to $\mathrm{TLR}^{-1-}$ and wild-type $C$. albicans and DSS-treated mice $(P<0.05)$. A damaged intestinal barrier in TLR $1^{-/-}$and TLR2 ${ }^{-/-}$mice following $C$. albicans colonization and DSS treatment is also consistent with the clinical symptoms and severe epithelial damage in the colons of these mice.

\section{Effects of DSS-induced colitis and C. albicans colonization on the growth of the $E$. coli population}

To assess the impact of DSS-induced colitis and C. albicans colonization on the growth of the E. coli population, the colonic luminal contents were analyzed at day 14 in all groups. We found that C. albicans alone did not induce any changes in the E. coli population. However, DSS-induced colitis promoted an increased $E$. coli population in $\mathrm{TLR} 1^{-1-}$, TLR $2^{-1-}$ and wild-type mice, but a decrease in $\mathrm{TLR}^{-1-}$ mice, regardless of C. albicans colonization (Fig. 5).

\section{Colonic expression levels of cytokines}

IL-1 $\beta$ and TNF are major pro-inflammatory cytokines that are rapidly released after tissue injury and fungal infection, so we determined their expression levels in the colons of mice challenged with C. albicans and treated with DSS (Fig. 6a-d). Both the mRNA expression levels and protein levels of IL- $1 \beta$ and TNF were significantly increased in the colons of $\mathrm{TLR} 1^{-1-}$ and $\mathrm{TLR}^{-1-}$ mice, whereas their expression levels were significantly reduced in $\mathrm{TLR}^{-1-}$ mice when compared to wild-type mice $(P<0.05)$. Interestingly, both TLR1 $1^{-/-}$ and TLR2 ${ }^{-1-}$ mice had higher expression levels of IL-10 and IL-17A when compared to TLR6 ${ }^{-1-}$ and wild-type mice (Figs. 5f, 6e, $P<0.05$ ).

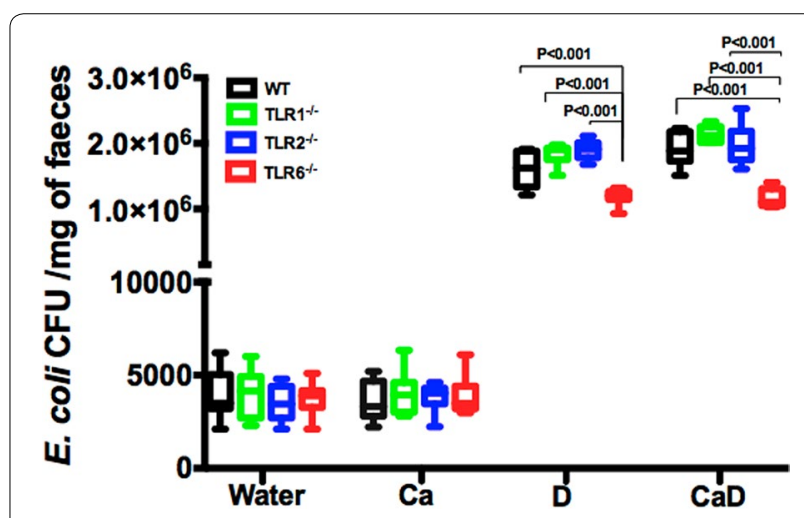

Fig. 5 Escherichia coli overgrowth in DSS-induced colitis. Four groups composed of controls (water), C. albicans alone (Ca), DSS alone (D), and C. albicans + DSS (CaD). Data are the mean \pm SD of 10 mice per group $\left(P<0.001\right.$ for $\mathrm{TLR}^{-/-}{ }^{-}, \mathrm{TLR}^{-/-}$, or wild-type mice versus $\mathrm{TLR6}^{-1-}$ mice) 

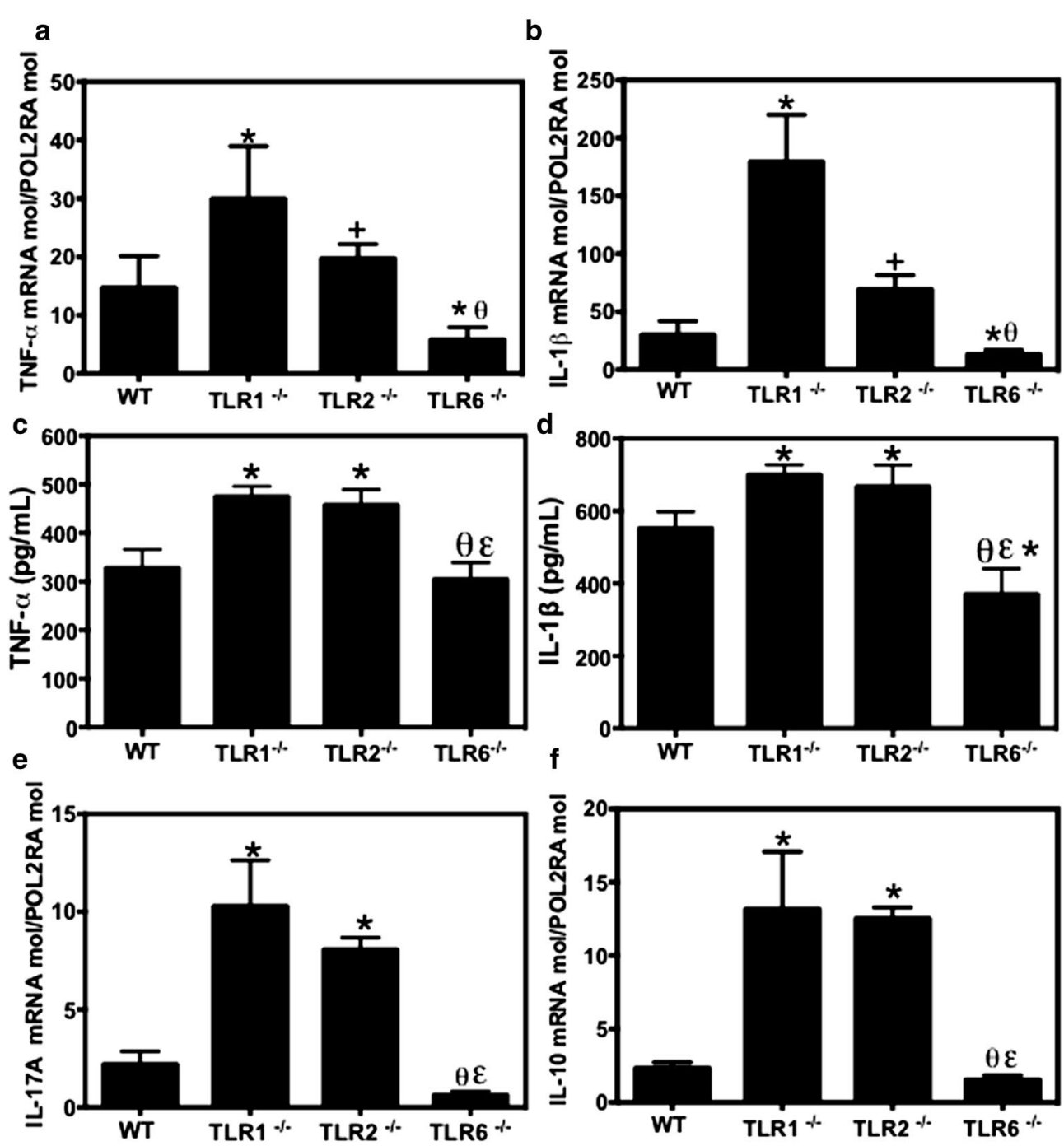

Fig. 6 Cytokine expression in C. albicans and DSS-induced colitis. $\mathbf{a}$, b Relative expression levels of TNF, and IL-1 $\beta$ mRNA in mouse colons. c, $\mathbf{d}$ Protein levels of TNF, and IL-1 $\beta$ in mouse colons. e, f Relative expression levels of IL-17, and IL-10 mRNA in mouse colons. Data are the mean \pm SE of 20 mice per group $(P<0.05) .{ }^{*} P<0.05$ for $\mathrm{TLR}^{-1-}$, TLR2 ${ }^{-1-}$, or TLR6 ${ }^{-1-}$ CaD mice versus wild-type $(\mathrm{WT}) \mathrm{CaD}$ mice. ${ }^{\theta} P<0.05$ for $\mathrm{TLR6}^{-/-} \mathrm{CaD}$ mice versus TLR1 ${ }^{-/-} \mathrm{CaD}$ mice, ${ }^{\varepsilon} P<0.05$ for $\mathrm{TLR6}^{-/-}$CaD mice versus TLR2 ${ }^{-/-}$CaD mice, ${ }^{+} P<0.05$ for TLR2 ${ }^{-/-}$CaD mice versus $\mathrm{TLR}^{-1-}$ CaD mice

Impact of TLR1, TLR2, or TLR6 deficiency on neutrophil-mediated C. albicans phagocytosis and death

Neutrophils are essential phagocytic cells involved in antifungal immunity. Therefore, we assessed the phagocytic activity of thioglycolate-elicited neutrophils from TLR $1^{-/-}$, TLR $2^{-/-}$, TLR6 ${ }^{-/-}$, and wild-type mice (Fig. 7a). Neutrophils and germinated C. albicans were co-incubated for $2 \mathrm{~h}$, and the number of viable fungi was quantified every $30 \mathrm{~min}$. We did not find any significant differences in C. albicans death. Additionally, live cell video microscopy showed no differences in the engulfment of $C$. albicans by $\mathrm{TLR} 1^{-1-}, \mathrm{TLR}^{-/-}$,
TLR6 $^{-/-}$, and wild-type neutrophils (data not shown). To examine whether neutrophils utilize TLR1, TLR2, or TLR6 for adhesion to C. albicans, we quantified the CFUs of $C$. albicans after $1 \mathrm{~h}$ of co-incubation with neutrophils (Fig. 7b). Neutrophils from TLR1 $1^{-1-}$ and $\mathrm{TLR}^{-l-}$ mice showed significantly less adherence to C. albicans than those from $\mathrm{TLR}^{-1-}$ and wild-type mice $(P<0.05)$. We also assessed the migration of neutrophils towards germinated $C$. albicans cells after $8 \mathrm{~h}$ of co-incubation using a transwell assay (Fig. 7c). We observed less TLR $1^{-1-}$ and TLR2 ${ }^{-/-}$neutrophil migration towards $C$. albicans than TLR6 ${ }^{-1-}$ and wild-type neutrophil migration $(P<0.05)$. 

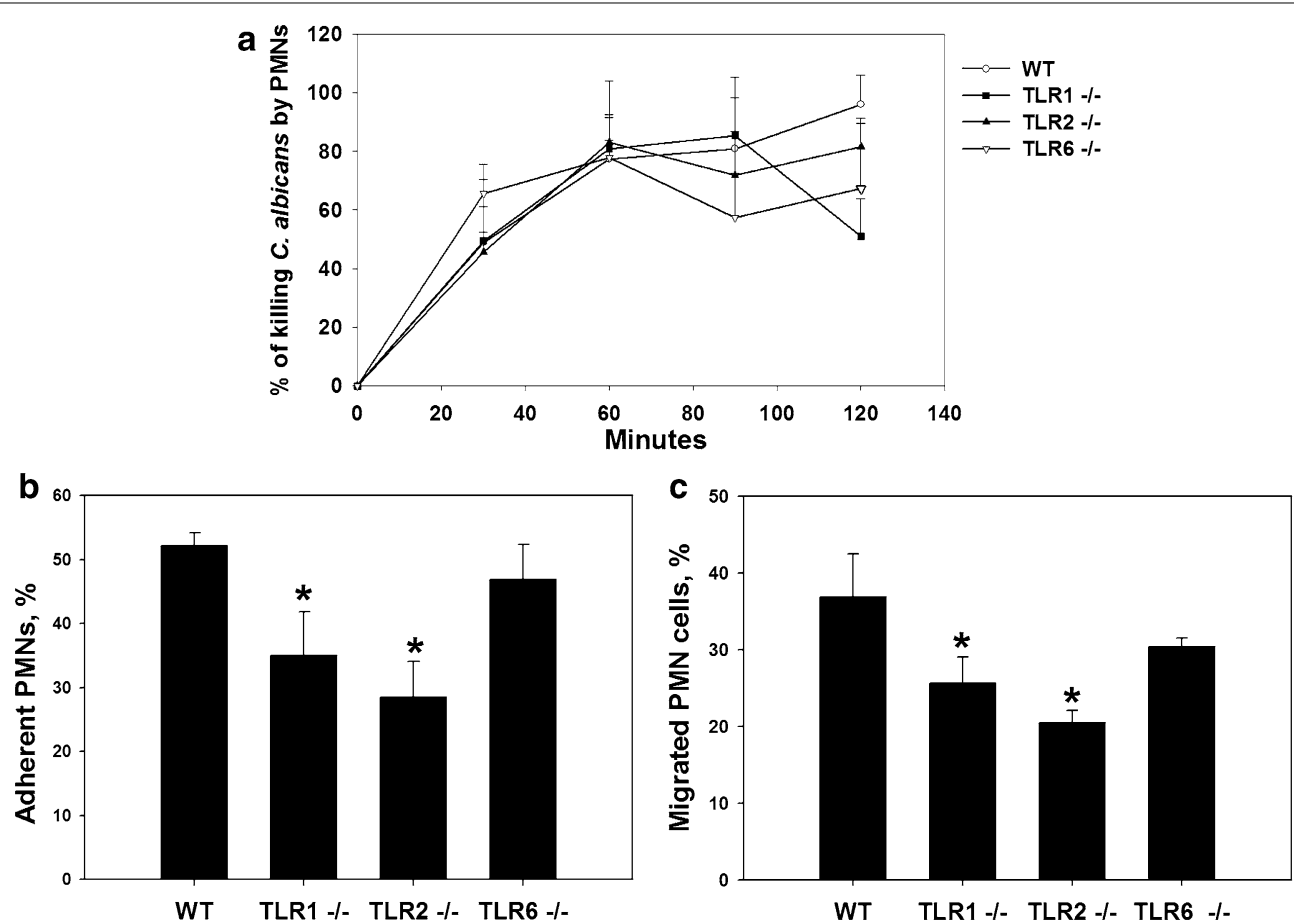

Fig. 7 Cell death, adhesion, and migration of neutrophils against C. albicans. a Cell death assay. $10^{5}$ C. albicans cells were suspended in RPMI and mixed with $5 \times 10^{5}$ neutrophils. C. albicans was counted every $30 \mathrm{~min}$. Results are expressed as percent death. $\mathbf{b}$ Adhesion of neutrophils to $C$. albicans. C. albicans yeasts were incubated for $1 \mathrm{~h}$ with neutrophils. Results are expressed as percent neutrophils adhering to yeasts. ${ }^{*} P<0.05$ for $\mathrm{TLR}^{-1-}$, and TLR2 ${ }^{-1-}$ neutrophils versus wild-type (WT) neutrophils. c Migration of neutrophils towards C. albicans. The migration of neutrophils towards C. albicans was performed using a transwell assay. Results are expressed as the percent neutrophils migrating from the upper to the lower chamber. Data are the mean \pm SE of three independent experiments $(P<0.05)$. ${ }^{*} P<0.05$ for TLR1 ${ }^{-/-}$, and TLR2 ${ }^{-/-}$neutrophils versus wild-type neutrophils

\section{Discussion}

IBD is characterized by microbial dysbiosis related to the abundance of a range of pathogenic microbial species, in particular, C. albicans [16-18]. C. albicans colonization is more frequent and more severe in patients with Crohn's disease than in control subjects [19]. The abundance of yeast in the gut can cause inflammation by activating cells through PRRs, including TLRs [20, 21]. TLRs are highly expressed in mucosal immune and epithelial cells and their triggering stimulates cytokine release and microbicidal activity [22]. In the present study, we investigated the role of TLR1, TLR2, and TLR6 in intestinal inflammation and C. albicans colonization. We previously developed a C. albicans colonization model, which is promoted by intestinal inflammation induced by DSS [23]. This C. albicans colonization is not maintained without the presence of intestinal inflammation; otherwise C. albicans is eliminated immediately in mice. In this DSS model, we employed a low concentration of DSS (1.5\%) to promote C. albicans colonization without inducing mouse mortality or severe colitis. In the present study, we compared DSS mice and mice treated with DSS and colonized with C. albicans. Initially, we performed experiments without DSS by administering C. albicans only to mice used as controls (TLR $1^{-1-}$, $\mathrm{TLR}^{-/-}$, TLR6 ${ }^{-1-}$, and wild-type mice). No C. albicans colonization was observed in any of these mouse strains a few days later. Interestingly, we observed that $\mathrm{TLR}^{-1-}$ and $\mathrm{TLR}^{-/-}$mice were more susceptible to DSS-induced colitis than TLR6 ${ }^{-1-}$ and wild-type mice. Rakoff-Nahoum et al. [10] demonstrated that mice deficient in TLR2 are highly susceptible to DSS-induced colitis, suggesting that TLRs contribute to prevent an aberrant immune response against the commensal flora. TLR2 forms heterodimers with either TLR1 or TLR6 to recognize different configurations of lipoproteins/ lipopeptides [6]. It has been reported that TLR2/TLR6 recognizes yeast-derived zymosan, which is mainly composed of mannans and $\beta$-glucans [24]. Jouault et al. [7, 8] showed that TLR2 binds to phospholipomannans of $C$. albicans in the presence of galectin-3, and $\beta$-mannosides of $C$. albicans, to induce pro-inflammatory responses by macrophages. TLR2 can also collaborate with dectin- 1 to bind fungal $\beta$-glucans $[25,26]$.

We observed that $C$. albicans colonization enhances the susceptibility of $\mathrm{TLR}^{-1-}$ and TLR2 $2^{-1-}$ mice, but not 
$\mathrm{TLR}^{-1-}$ mice, to intestinal inflammation. $\mathrm{TLR}^{-1-}$ mice were more resistant to DSS-induced colitis as reflected by lower clinical and histologic scores for inflammation and mortality. These data corroborate findings from a recent study which showed that mice deficient in $\mathrm{TLR}^{-1-}$ are protected from intestinal inflammation and have a low number of Th17 cells [27]. This evidence emphasizes the role played by TLR6 in the induction of an inflammatory response to C. albicans sensing. Netea et al. [28] showed that, in contrast to TLR1, TLR6 is involved in the recognition of C. albicans and modulation of the Th1/Th2 cytokine balance. Moreover, TLR2 ${ }^{-1-}$ mice had significantly impaired survival to Candida infection, indicating that TLR2 confers protection against primary disseminated candidiasis [3].

All TLRs except TLR3 are expressed by neutrophils, which represent the primary first line of defense against C. albicans infection $[1,29]$. In the present study, neutrophils from TLR1, TLR2, and TLR6 deficient mice were not affected in terms of $C$. albicans phagocytosis. On the other hand, adhesion and migration of neutrophils from TLR1 ${ }^{-1-}$ and TLR2 ${ }^{-1-}$ mice to C. albicans was impaired. In line with these findings, neutrophils and macrophages from TLR $2^{-1-}$ mice internalized and killed C. albicans as efficiently as wild-type cells [4]. Moreover, Weindl et al. [30] showed neutrophil-dependent TLR4-mediated protective mechanisms against $C$. albicans infection at epithelial surfaces, a phenomenon that was independent of neutrophil migration to $C$. albicans or epithelial cells.

Analysis of colon cytokine expression revealed that TLR1 deficiency strongly up-regulated TNF, IL-1 $\beta$, and IL17A, whereas TLR6 deletion down-regulated TNF, IL-1 $\beta$, and IL17A colonic expression when compared to controls. These data suggest that TLR1 plays a role in dampening the cytokine response and preventing excessive immune-mediated tissue damage, whereas TLR6 is involved in exacerbating the inflammatory response associated with tissue damage upon recognition of $C$. albicans and DSS-induced colitis [31, 32]. Notably, $C$. albicans colonization increased TLR2 expression in the colons of DSS-treated wild-type mice, whereas TLR2 expression was reduced in galectin-3 deficient mice leading to high pro-inflammatory cytokine expression and aggravated intestinal inflammation [20].

IL-10 is essential for host defense against $C$. albicans infection and can limit the potential tissue damage caused by inflammation [33]. In the present study, we showed that in contrast to the state of TLR6 ${ }^{-1-}$ mice, DSS-induced colitis induced the production of proand anti-inflammatory cytokines, including IL-10, in TLR1 ${ }^{-1-}$ mice. In line with this study, the absence of TLR6 dramatically increased survival and decreased IL-10 production, whereas the absence of TLR1 led to decreased survival and higher IL-10 levels in mice infected with Yersinia pestis, suggesting that TLR6 is a distinct TLR receptor driving regulatory IL-10 responses [34]. Netea et al. [35] showed that TLR activation, in particular TLR2, can suppress the immune defense against $C$. albicans through the induction of IL-10 and regulatory T-cells.

In this study, we observed that $\mathrm{TLR}^{-1-}$ mice eliminate $C$. albicans from the digestive tract more rapidly than TLR $1^{-1-}$ and TLR2 ${ }^{-1-}$ mice. In particular, colonization in the stomach was dramatically higher in $\mathrm{TLR}^{-1-}$ mice, supporting the notion of a protective role of TLR1 and TLR2 against C. albicans colonization. Additionally, in agreement with our results, TLR1 gene polymorphisms have been associated with an increased susceptibility to candidemia in patients [21]. In addition, polymorphisms in the TLR2 gene have been identified as a risk factor for candidemia [36, 37]. Although TLR2 interacts with a large number of nonTLR molecules, in particular Galectin-3 and Dectin1-mediated ERK/MAPK activation [8, 25], allowing the recognition of fungal ligand varieties, in our study, we found that mice deficient in TLR1 had higher levels of colonization with $C$. albicans in the stomach and colon than TLR2 ${ }^{-1-}$ mice. These data show that TLR1 is more involved in C. albicans elimination from the gut than TLR2, suggesting that the absence of TLR1 can have a great impact on the formation of the heterodimer TLR1/TLR2 when compared to the absence of TLR2. Van Duin et al. [38] showed that alterations in baseline TLR1 surface expression were increased in elderly individuals, whereas TLR2 surface expression was unaffected, suggesting that the defect in TLR1 expression can contribute to the increased infection-related morbidity and mortality observed in elderly individuals.

Changes in commensal bacterial diversity can differentially modulate mucosal TLR responsiveness, leading to TLR-mediated hyper- or hypo-reactive immune responses $[10,39,40]$. In the present study, intestinal inflammation alone was sufficient to promote the overgrowth of $E$. coli. Additionally, both inflammation and $C$. albicans colonization maintained $E$. coli overgrowth in TLR $1^{-/-}$, TLR2 ${ }^{-1-}$ and wild-type mice when compared to that in $\mathrm{TLR}^{-1-}$ mice. These data are consistent with Lupp et al. [41] finding which suggested that the commensal E. coli increased during colitis and displayed a strong pro-inflammatory potential. Ey et al. [14] showed that an unaltered microbiota was required for colitis exacerbation in TLR2/MDR1A double-knockout mice once protection from colitis was observed upon antibiotic treatment.

In the present study, intestinal inflammation alone was sufficient to promote the overgrowth of $E$. coli. Additionally, 
both inflammation and C. albicans colonization maintained $E$. coli overgrowth in TLR1 ${ }^{-1-}$, TLR2 $2^{-l-}$ and wildtype mice when compared to that in TLR6 ${ }^{-1-}$ mice. These data are consistent with Lupp et al. [41] finding which suggested that the commensal E. coli increased during colitis and displayed a strong pro-inflammatory potential.

Experimental and clinical studies emphasize the role of the serologic response during the development of IBD [20, 42]. Crohn's disease patients who express high levels of serologic markers experience more aggressive disease, suggesting that the presence of Crohn's disease marker antibodies reflect a specific mucosal immunemediated response [43]. We observed that mannanemia was elevated only in TLR1 $1^{-/-}$and TLR2 ${ }^{-/-}$mice. High mannanemia in $\mathrm{TLR}^{-/-}$and $\mathrm{TLR} 2^{-/-}$mice was correlated with increased intestinal permeability, which facilitates the passage of fungi into the bloodstream. Clinically, Pierik et al. [15] showed a negative association between TLR6 S249P and ulcerative colitis with proctitis. In our study, we found in a clinical cohort of 26 healthy subjects (between 25- and 65-years-old) an association between the TLR6 rs5743810 homozygous wild-type genotype and ASCA (anti-Saccharomyces cerevisiae antibody) level $(P=0.0317)$. Homozygous healthy subjects (TLR6 A/A wild-type) have significantly higher ASCA levels than heterozygous (TLR6 A/G) and homozygous mutants (TLR6 G/G) indicating a possible association of this TLR6 rs5743810 polymorphism with IBD (Additional file 1). These clinical data corroborate findings from our experimental study, which showed that deletion of TLR6 decreased the circulating mannan level in mice. Taylor et al. [44] showed that among African Americans, women who carried 1 or 2 of the TLR6 rs5743810 alleles had decreased odds of endometritis and upper genital tract infection and there was a similar trend among white participants. We intend to widen our study to larger groups of healthy subjects and patients with $\mathrm{CD}$.

\section{Conclusions}

DSS-induced colitis promoted the overgrowth of E. coli and $C$. albicans in the gut. TLR1 and TLR6 had not the same effects on the TLR2-mediated immune response. Deletion of TLR1 exacerbated intestinal inflammation in response to $C$. albicans colonization, resulting in colonic injury and mouse mortality. Conversely, deletion of TLR6 impacted on the intestinal inflammation via the modulation of cytokine expressions and promoted the elimination of C. albicans. Overall, this study emphasizes the role of TLRs in the modulation of intestinal inflammation and C. albicans colonization and shows the involvement of TLR1 in the homeostasis of intestinal epithelium and the impact of TLR6 on both intestinal inflammation and the host defense.

\section{Methods}

Yeast strain

Candida albicans Sc5314 strain was used throughout this study [45]. C. albicans isolates were grown in Sabouraud's dextrose broth at $37^{\circ} \mathrm{C}$ in a shaking incubator for $18 \mathrm{~h}$.

\section{Animals}

Female C57BL/6 mice (8-10-weeks-old) were purchased from Charles River Laboratories (France). All mice were fed with a standard chow diet (Scientific Animal Food and Engineering, SAFE diet-A04, France). This diet contained neither yeast cells nor yeast cell extract. The strain description and use of TLR $1^{-1-}$, TLR2 ${ }^{-/-}$, and TLR6 ${ }^{-1-}$ C57BL/6 mice has been provided elsewhere [46]. WT and $\mathrm{TLRs}^{-1-}$ mice were each distributes into control group and experimental groups and two sets of experiments (a total of 90 mice/experiment) were performed independently. A group of healthy mice was used as controls (CTL, $\mathrm{n}=5 \mathrm{WT}$ and $\mathrm{n}=15$ TLR deficient mice). A second group of mice was gavaged orally with C. albicans without any other treatment $(\mathrm{Ca}, \mathrm{n}=10 \mathrm{WT}$ and $\mathrm{n}=30$ TLR deficient mice). A third group was treated with DSS alone (D, $\mathrm{n}=10 \mathrm{WT}$ and $\mathrm{n}=30$ TLR deficient mice). A fourth group was treated with DSS and gavaged orally with $C$. albicans $(\mathrm{CaD}, \mathrm{n}=20 \mathrm{WT}$ and $\mathrm{n}=60$ TLR deficient mice). Mouse survival and body weight were monitored daily for 14 days. All efforts were made to minimize animal suffering. Mice with a body weight loss of $>20 \%$ initial body weight were humanely euthanized by inhalation of $5 \%$ isoflurane followed by cervical dislocation.

\section{Inoculum preparation and induction of colitis}

Each animal was inoculated on day 1 by single oral gavage with $200 \mu \mathrm{L}$ of phosphate-buffered saline (PBS) containing $10^{7} \mathrm{C}$. albicans cells. Mice were then given 1.5\% DSS (MW 36-50 kDa; MP Biomedicals, LLC, Germany) in drinking water from day 1 to day 14, to induce intestinal inflammation. The presence of yeasts in the intestinal tract was assessed daily by performing plate counts from feces (approximately $0.1 \mathrm{~g} /$ sample) [20]. Stool samples were daily collected from each tagged animal and suspended in $1 \mathrm{~mL}$ PBS, and plated onto Candi-Select medium (Bio-Rad, Marnes la Coquette, France). The colonies were counted after $48 \mathrm{~h}$ incubation at $37^{\circ} \mathrm{C}$. The results were noted as colony forming units $(\mathrm{CFU}) / \mu \mathrm{g}$ of feces. To assess $C$. albicans colonization of the gut, the gastrointestinal tract was removed from sacrificed mice, and the stomach and colon were separated and analyzed. The tissues were cut longitudinally. After removal of intestinal contents, the tissues were washed several times with PBS to minimize surface contamination from organisms present in the lumen [47]. Serial dilutions of homogenates were plated onto Sabouraud's agar plates, 
and the results were expressed as C. albicans CFU/mg of tissue. For the $E$. coli identification, the colonic luminal faecal samples at 14 days were collected from each tagged animal and plated onto MacConkey agar (Sigma-Aldrich) containing Fluconazole (Fresenius Kabi, $60 \mathrm{mg} / \mathrm{L}$ ) to suppress the growth of fungal cells. The plates were incubated at $37{ }^{\circ} \mathrm{C}$ and examined at 24 and $48 \mathrm{~h}$ later. For the identification of bacteria, colonies were mixed with $1.5 \mu \mathrm{L}$ of matrix solution ( $\alpha$-cyano-4-hydroxycinnamic acid [HCCA]; Bruker Daltonics) dissolved in 50\% acetonitrile, $47.5 \%$ water, and $2.5 \%$ trifluoroacetic acid and allowed to dry prior to analysis using the MALDI-TOF MS (Microflex-Bruker Daltonics).

\section{Assessment of clinical parameters}

The body weight and mortality of the mice was recorded daily. The data were expressed as mean percent change from initial body weight. Clinical scores ranging from 0 to 8 were calculated as described elsewhere $[20,48]$.

\section{Intestinal permeability in vivo}

Mice were given DX-4000-FITC (FD4000, SigmaAldrich, France) by oral gavage (500 $\mathrm{mg} / \mathrm{kg}$ body weight) [49]. After $4 \mathrm{~h}$, blood samples were collected and DX4000-FITC concentrations were quantified with a Mithras ${ }^{\circledR}$ fluorescence spectrophotometer (Berthold technologies, France).

\section{Histologic score}

The rings of the transverse part of the colon were fixed overnight in $4 \%$ paraformaldehyde-acid, embedded in paraffin, and histological analysis was performed by staining the cross-sections (4- $\mu \mathrm{m}$ thick) with hematoxylin-eosin (Sigma-Aldrich, France). Histologic scores were evaluated by two independent blinded investigators who observed two sections per mouse at magnifications of $\times 10$ and $\times 100$. The scores were determined as described by Siegmund et al. [48] and the sections were evaluated for the following two subscores: (1) a score for the presence and confluence of inflammatory cells, in the lamina propria and submucosa or transmural extension; and (2) a score for epithelial damage, focal lymphoepithelial lesions, mucosal erosion and/ or ulceration and extension to the bowel wall. The two subscores were added together and the combined histologic score ranged from 0 (no changes) to 6 (extensive cell infiltration and tissue damage). Immunohistofluorescence staining of the colons was performed on dewaxed and PBS-rehydrated paraffin-embedded colon sections. The tissue sections were incubated for $30 \mathrm{~min}$ at room temperature in $1 \%$ bovine serum albumin (BSA) diluted in PBS. Slides were washed with PBS and incubated for $1 \mathrm{~h}$ at room temperature with anti-mouse
CD281-TLR1 (eBioscience), anti-mouse CD282-TLR2 (eBioscience), and anti-mouse TLR6 (ab37072, Abcam) antibodies, which were diluted 1:100 in PBS. After 3 washes with $\mathrm{PBS}$, the sections were incubated with fluorescein isothiocyanate-conjugated anti-rabbit or anti-rat antibodies (Zymed Laboratories) for $60 \mathrm{~min}$ at $37^{\circ} \mathrm{C}$ [50]. The sections were then washed with PBS and counterstained with DAPI. The sections were then examined by confocal microscopy (Zeiss LSM710, diode $561 \mathrm{~nm}$ DPSS).

\section{Measurement of mannan antigen in mouse serum}

Mannan antigen was measured using a Platelia ${ }^{\mathrm{TM}}$ Candida Ag (mannan) kit (Bio-Rad) according to the manufacturer's instructions. Absorbance was read at $450 \mathrm{~nm}$ (reference filter, $620 \mathrm{~nm}$ ) in a microplate reader (Bio-Rad) after addition of tetramethylbenzydine [20]. Results were expressed as optical density (OD).

Real-time mRNA quantification and measurement of cytokine levels in colons

Total RNA was isolated from colon samples using a NucleoSpin RNA II kit (Macherey-Nagel) following the manufacturer's instructions, with 20-50 units of DNase I (RNase-free) at $37{ }^{\circ} \mathrm{C}$ for $30 \mathrm{~min}$ to avoid contamination with genomic DNA. RNA was quantified with a Nanodrop (Thermo Scientific, Wilmington, $D E)$. Reverse transcription of mRNA was carried out according to the manufacturer's instructions (Applied Biosystems). Briefly, reverse transcription of mRNA was performed in a final volume of $20 \mu \mathrm{L}$, from $1 \mu \mathrm{g}$ of total RNA, using 50 units of reverse transcriptase (Applied Biosystems) with $200 \mathrm{nmol}$ oligo (dT) 12-18. Polymerase chain reaction (PCR) was then performed on this mixture using the one-step system (Applied Biosystems) with Fast SYBR green (Applied Biosystems). Amplification was carried out in a total volume of $12 \mu \mathrm{L}$ containing $0.25 \mu \mathrm{L}$ of each primer (Table 1) and $2.5 \mu \mathrm{L}$ of cDNA prepared as described above. SYBR green dye intensity was analyzed using step-one software. All results were normalized to the reference gene POLR2A [51]. Cytokine concentrations from colons were measured using a commercial ELISA kit according to the manufacturer's instructions (eBioscience, San Diego, CA).

\section{Adhesion, migration and phagocytosis}

Mice were injected intraperitoneally with $500 \mu \mathrm{L}$ sterile thioglycolate $(3 \% \mathrm{wt} / \mathrm{vol})$. After $6 \mathrm{~h}$, mice were anaesthetized using 5\% isoflurane and sacrificed by cervical dislocation. Neutrophils were collected by washing the peritoneal cavity with $5 \mathrm{~mL}$ of cold sterile PBS [52]. Neutrophils were plated in RPMI medium 
Table 1 Mouse oligonucleotide sequences

\begin{tabular}{ll}
\hline Primers & Sequence $\left(\mathbf{5}^{\prime} \mathbf{- 3}^{\prime} \mathbf{)}\right.$ \\
\hline POLR2A S & CCCACAACCAGCTATCCTCAA \\
POLR2A AS & GGTGCTGTGGGTACGGATACA \\
IL-1 $\beta$ S & AGCTCTCCACCTCAATGGAC \\
IL-1 $\beta$ AS & AGGCCACAGGTATTTTGTCG \\
TNF-a S & CCACCACGCTCTTCTGTCTA \\
TNF-a AS & GAGGCCATTTGGAACTTCT \\
IL-17A S & GCAAGAGATCCTGGTCCTGA \\
IL-17A AS & AGCATCTTCTCGACCCTGAA \\
IL-10S & CAGTACAGCCGGGAAGACAATAA \\
IL-10 AS & CCGCAGCTCTAGGAGCATGT
\end{tabular}

$S$ sense, $A S$ antisense

supplemented with $10 \%$ heat-inactivated fetal bovine serum (Gibco, France) and $1 \%$ penicillin-streptomycin, and incubated for $1 \mathrm{~h}$ at $37^{\circ} \mathrm{C}$ in $5 \% \mathrm{CO}_{2}$. Nonadherent cells were collected and centrifuged to isolate the neutrophil pellet. Viability and neutrophil counts were determined by the trypan blue exclusion method (Gibco, France).

Neutrophil adhesion assays were performed as described previously [53, 54]. Briefly, 96-well tissue culture plates (Corning) were pre-coated with polyvinylpyrolidone (PVP, Sigma-Aldrich) and washed with PBS. Then, $10^{4}$ C. albicans yeasts in $0.02 \mathrm{~mL}$ RPMI were added to each well and incubated overnight at $37{ }^{\circ} \mathrm{C}$ to germinate. To assess neutrophil adhesion to C. albicans, yeasts were incubated in YNB broth to prevent germination. The supernatant was removed after incubation, and adherent fungi were carefully washed with PBS. Approximately $5 \times 10^{4}$ calcein-labeled neutrophils were added to each well and the plates were then incubated at $37^{\circ} \mathrm{C}$ for $1 \mathrm{~h}$. After several washes, the percentage of adherent neutrophils was determined using a Mithras ${ }^{\circledR}$ fluorometer. Neutrophil adhesion to PVP was subtracted from that of the experimental samples. Results were expressed as percent adhesion. A migration assay was performed as described previously [53, 54]. Briefly, $200 \mu \mathrm{L}$ calcein-labeled washed neutrophils were added to the upper chamber of the transwell devices (Costar Transwell inserts in a 24-well plate format), and $600 \mu \mathrm{L}$ RPMI with $10^{6} \mathrm{C}$. albicans yeast was added to the lower chamber. Plates were placed in a humidified incubator at $37{ }^{\circ} \mathrm{C}$ and $5 \% \mathrm{CO}_{2}$ for $8 \mathrm{~h}$. To perform the cell death assay, $10^{5}$ fungal cells were suspended in $0.2 \mathrm{~mL}$ RPMI, and mixed with $5 \times 10^{5}$ (1:5 ratio) neutrophils. The neutrophil/fungus mixtures were incubated at $37^{\circ} \mathrm{C}$ with slow shaking for $2 \mathrm{~h}$. To determine the extent of cell death/phagocytosis, aliquots of the cell/fungal suspension were taken every $30 \mathrm{~min}$, diluted with PBS, and subsequently plated in serial dilutions on Sabouraud's dextrose agar plates. The neutrophils were not lysed before plating, and all fungal cells that remained ingested were recorded as "killed."

\section{Statistical analysis}

Data were expressed as the mean $\pm \mathrm{SE}$ of 20 mice in each group. Statistical analysis was performed with Prism 4.0 from GraphPad and XLSTAT. Data were analyzed using the Mann-Whitney U test to compare pairs of groups. The log-rank test was used to analyze mouse survival. Differences were considered significant when the $P$ value was $<0.05$.

\section{Additional file}

Additional file 1. Association between TLR6 rs5743810 homozygous genotype wild-type and ASCA level.

\section{Authors' contributions}

$L C, H V$, DLR, and SJ performed the experiments. LC, HV, LD, LR, TJ, DP, BS, TC, TR, and SJ analyzed data. LC, HV, LD, LR, TJ, DP, BS, TC, TR, and SJ interpreted results of experiments. DLR, LD, LR, TC, and TR contributed reagents/materials/analysis tools. SJ designed the experiments and drafted the manuscript. All authors read and approved the final manuscript.

\section{Author details}

${ }^{1}$ INSERM U995/2, Université Lille Nord de France, 1 Place Verdun, 59000 Lille, France. ${ }^{2}$ U995-LIRIC, Lille Inflammation Research International Center, University Lille2, 59000 Lille, France. ${ }^{3}$ Service de Parasitologie Mycologie, Pôle de Biologie Pathologie Génétique, CHU Lille, 59000 Lille, France. ${ }^{4}$ Infectious Diseases Service, Department of Medicine, Lausanne University Hospital, Lausanne, Switzerland. ${ }^{5}$ Department of Experimental Medicine and Biochemical Sciences, University of Perugia, Perugia, Italy.

\section{Acknowledgements}

The authors kindly thank Céline Villenet and Shéhérazade Sebda for their assistance in SNP genotyping. The authors would like to thank the digestScience Foundation for their support.

\section{Competing interests}

The authors declare that they have no competing interests.

\section{Availability of data and materials}

The datasets used and/or analyzed during the current study available from the corresponding author on reasonable request.

\section{Consent for publication}

An informed written consent was obtained from the healthy donors.

\section{Ethics approval and consent to participate}

Experiments were performed according to the protocols approved by the subcommittee for Research Animal Care of the Regional Hospital Centre of Lille, France, and in accordance with European legal and institutional guidelines (86/609/CEE) for the care and use of laboratory animals.

\section{Funding}

This work was supported by the FP7 Health 260338 "ALLFUN" Project "Fungi in the setting of inflammation, allergy and auto-immune diseases: translating basic science into clinical practices". TR and TC are supported by the Swiss National Science Foundation (Grants 320030_149511 and 310030_138488) and the Faculty of Biology and Medicine from the University of Lausanne (Interdisciplinary grant CellAirTox to TR).

Received: 21 December 2016 Accepted: 3 February 2017

Published online: 15 February 2017 


\section{References}

1. Gil ML, Gozalbo D. Role of toll-like receptors in systemic Candida albicans infections. Front Biosci (Landmark Ed). 2009;14:570-82.

2. Savva A, Roger T. Targeting toll-like receptors: promising therapeutic strategies for the management of sepsis-associated pathology and infectious diseases. Front Immunol. 2013;4:387.

3. Villamon E, Gozalbo D, Roig P, O'Connor JE, Fradelizi D, Gil ML. Toll-like receptor- 2 is essential in murine defenses against Candida albicans infections. Microbes Infect. 2004;6:1-7.

4. Bellocchio S, Montagnoli C, Bozza S, Gaziano R, Rossi G, Mambula SS, Vecchi A, Mantovani A, Levitz SM, Romani L. The contribution of the tolllike/IL-1 receptor superfamily to innate and adaptive immunity to fungal pathogens in vivo. J Immunol. 2004;172:3059-69.

5. van der Graaf CA, Netea MG, Verschueren I, van der Meer JW, Kullberg BJ. Differential cytokine production and toll-like receptor signaling pathways by Candida albicans blastoconidia and hyphae. Infect Immun. 2005;73:7458-64.

6. Takeda K, Takeuchi O, Akira S. Recognition of lipopeptides by toll-like receptors. J Endotoxin Res. 2002:8:459-63.

7. Jouault T, Ibata-Ombetta S, Takeuchi O, Trinel PA, Sacchetti P, Lefebvre P, Akira S, Poulain D. Candida albicans phospholipomannan is sensed through toll-like receptors. J Infect Dis. 2003;188:165-72.

8. Jouault T, El Abed-El Behi M, Martinez-Esparza M, Breuilh L, Trinel PA, Chamaillard M, Trottein F, Poulain D. Specific recognition of Candida albicans by macrophages requires galectin-3 to discriminate Saccharomyces cerevisiae and needs association with TLR2 for signaling. J Immunol. 2006;177:4679-87.

9. Lundin A, Bok CM, Aronsson L, Bjorkholm B, Gustafsson JA, Pott S, Arulampalam V, Hibberd M, Rafter J, Pettersson S. Gut flora, toll-like receptors and nuclear receptors: a tripartite communication that tunes innate immunity in large intestine. Cell Microbiol. 2008;10:1093-103.

10. Rakoff-Nahoum S, Paglino J, Eslami-Varzaneh F, Edberg S, Medzhitov R. Recognition of commensal microflora by toll-like receptors is required for intestinal homeostasis. Cell. 2004:118:229-41.

11. Albert EJ, Duplisea J, Dawicki W, Haidl ID, Marshall JS. Tissue eosinophilia in a mouse model of colitis is highly dependent on TLR2 and independent of mast cells. Am J Pathol. 2011;178:150-60.

12. Henckaerts $L$, Pierik $M$, Joossens $M$, Ferrante $M$, Rutgeerts $P$, Vermeire $S$. Mutations in pattern recognition receptor genes modulate seroreactivity to microbial antigens in patients with inflammatory bowel disease. Gut. 2007:56:1536-42

13. Netea MG, Kullberg BJ, de Jong DJ, Franke B, Sprong T, Naber TH, Drenth JP, Van der Meer JW. NOD2 mediates anti-inflammatory signals induced by TLR2 ligands: implications for Crohn's disease. Eur J Immunol. 2004;34:2052-9.

14. Ey B, Eyking A, Klepak M, Salzman NH, Gothert JR, Runzi M, Schmid KW, Gerken G, Podolsky DK, Cario E. Loss of TLR2 worsens spontaneous colitis in MDR1A deficiency through commensally induced pyroptosis. J Immunol. 2013;190:5676-88.

15. Pierik M, Joossens $S$, Van Steen $K$, Van Schuerbeek N, Vlietinck R, Rutgeerts P, Vermeire $S$. Toll-like receptor-1, -2 , and -6 polymorphisms influence disease extension in inflammatory bowel diseases. Inflamm Bowel Dis. 2006;12:1-8.

16. Darfeuille-Michaud A, Boudeau J, Bulois P, Neut C, Glasser AL, Barnich N, Bringer MA, Swidsinski A, Beaugerie L, Colombel JF. High prevalence of adherent-invasive Escherichia coli associated with ileal mucosa in Crohn's disease. Gastroenterology. 2004;127:412-21.

17. Li Q, Wang C, Tang C, He Q, Li N, Li J. Dysbiosis of gut fungal microbiota is associated with mucosal inflammation in Crohn's disease. J Clin Gastroenterol. 2014;48:513-23.

18. Standaert-Vitse A, Jouault T, Vandewalle P, Mille C, Seddik M, Sendid B, Mallet JM, Colombel JF, Poulain D. Candida albicans is an immunogen for anti-Saccharomyces cerevisiae antibody markers of Crohn's disease. Gastroenterology. 2006;130:1764-75.

19. Standaert-Vitse A, Sendid B, Joossens M, Francois N, Vandewalle-E Khoury P, Branche J, Van Kruiningen H, Jouault T, Rutgeerts P, GowerRousseau C, et al. Candida albicans colonization and ASCA in familia Crohn's disease. Am J Gastroenterol. 2009;104:1745-53.

20. Jawhara S, Thuru X, Standaert-Vitse A, Jouault T, Mordon S, Sendid B, Desreumaux P, Poulain D. Colonization of mice by Candida albicans is promoted by chemically induced colitis and augments inflammatory responses through galectin-3. J Infect Dis. 2008;197:972-80.
21. Plantinga TS, Johnson MD, Scott WK, van de Vosse E, Velez Edwards DR, Smith PB, Alexander BD, Yang JC, Kremer D, Laird GM, et al. Toll-like receptor 1 polymorphisms increase susceptibility to candidemia. J Infect Dis. 2012;205:934-43.

22. Vora P, Youdim A, Thomas LS, Fukata M, Tesfay SY, Lukasek K, Michelsen KS, Wada A, Hirayama T, Arditi M, Abreu MT. Beta-defensin-2 expression is regulated by TLR signaling in intestinal epithelial cells. J Immunol. 2004;173:5398-405

23. Jawhara S, Poulain D. Saccharomyces boulardii decreases inflammation and intestinal colonization by Candida albicans in a mouse model of chemically-induced colitis. Med Mycol. 2007:45:691-700.

24. Ozinsky A, Underhill DM, Fontenot JD, Hajjar AM, Smith KD, Wilson CB, Schroeder $L$, Aderem A. The repertoire for pattern recognition of pathogens by the innate immune system is defined by cooperation between toll-like receptors. Proc Natl Acad Sci USA. 2000;97:13766-71.

25. Dillon S, Agrawal S, Banerjee K, Letterio J, Denning TL, Oswald-Richter K, Kasprowicz DJ, Kellar K, Pare J, van Dyke T, et al. Yeast zymosan, a stimulus for TLR2 and dectin-1, induces regulatory antigen-presenting cells and immunological tolerance. J Clin Invest. 2006;116:916-28.

26. Gantner BN, Simmons RM, Canavera SJ, Akira S, Underhill DM. Collaborative induction of inflammatory responses by dectin-1 and Toll-like receptor 2. J Exp Med. 2003;197:1107-17.

27. Morgan ME, Koelink PJ, Zheng B, den Brok MH, van de Kant HJ, Verspaget HW, Folkerts G, Adema GJ, Kraneveld AD. Toll-like receptor 6 stimulation promotes T-helper 1 and 17 responses in gastrointestinal-associated lymphoid tissue and modulates murine experimental colitis. Mucosal Immunol. 2014;7:1266-77.

28. Netea MG, van de Veerdonk F, Verschueren I, van der Meer JW, Kullberg BJ. Role of TLR1 and TLR6 in the host defense against disseminated candidiasis. FEMS Immunol Med Microbiol. 2008;52:118-23.

29. Hayashi F, Means TK, Luster AD. Toll-like receptors stimulate human neutrophil function. Blood. 2003;102:2660-9.

30. Weind G, Naglik JR, Kaesler S, Biedermann T, Hube B, Korting HC, Schaller M. Human epithelial cells establish direct antifungal defense through TLR4-mediated signaling. J Clin Invest. 2007;117:3664-72.

31. Bozza S, Zelante T, Moretti S, Bonifazi P, DeLuca A, D'Angelo C, Giovannini G, Garlanda C, Boon L, Bistoni F, et al. Lack of toll IL-1R8 exacerbates Th17 cell responses in fungal infection. J Immunol. 2008;180:4022-31.

32. Netea MG, Van Der Graaf CA, Vonk AG, Verschueren I, Van Der Meer JW, Kullberg BJ. The role of toll-like receptor (TLR) 2 and TLR4 in the host defense against disseminated candidiasis. J Infect Dis. 2002;185:1483-9.

33. Ouyang W, Rutz S, Crellin NK, Valdez PA, Hymowitz SG. Regulation and functions of the IL-10 family of cytokines in inflammation and disease. Annu Rev Immunol. 2011:29:71-109.

34. Depaolo RW, Tang F, Kim I, Han M, Levin N, Ciletti N, Lin A, Anderson D, Schneewind O, Jabri B. Toll-like receptor 6 drives differentiation of tolerogenic dendritic cells and contributes to LcrV-mediated plague pathogenesis. Cell Host Microbe. 2008;4:350-61.

35. Netea MG, Sutmuller R, Hermann C, Van der Graaf CA, Van der Meer JW, van Krieken JH, Hartung T, Adema G, Kullberg BJ. Toll-like receptor 2 suppresses immunity against Candida albicans through induction of $\mathrm{IL}-10$ and regulatory T cells. J Immunol. 2004;172:3712-8

36. Woehrle T, Du W, Goetz A, Hsu HY, Joos TO, Weiss M, Bauer U, Brueckner UB, Marion Schneider E. Pathogen specific cytokine release reveals an effect of TLR2 Arg753Gln during Candida sepsis in humans. Cytokine. 2008;41:322-9.

37. Rosentul DC, Delsing CE, Jaeger M, Plantinga TS, Oosting M, Costantini I, Venselaar H, Joosten LA, van der Meer JW, Dupont B, et al. Gene polymorphisms in pattern recognition receptors and susceptibility to idiopathic recurrent vulvovaginal candidiasis. Front Microbiol. 2014;5:483.

38. van Duin D, Mohanty S, Thomas V, Ginter S, Montgomery RR, Fikrig E, Allore HG, Medzhitov R, Shaw AC. Age-associated defect in human TLR1/2 function. J Immunol. 2007;178:970-5.

39. Rose WA 2nd, McGowin CL, Spagnuolo RA, Eaves-Pyles TD, Popov VL, Pyles RB. Commensal bacteria modulate innate immune responses of vaginal epithelial cell multilayer cultures. PLoS ONE. 2012;7:e32728.

40. Elluru SR, Kaveri SV, Bayry J. The protective role of immunoglobulins in fungal infections and inflammation. Semin Immunopathol. 2015;37:187-97.

41. Lupp C, Robertson ML, Wickham ME, Sekirov I, Champion OL, Gaynor EC, Finlay BB. Host-mediated inflammation disrupts the intestinal microbiota 
and promotes the overgrowth of Enterobacteriaceae. Cell Host Microbe. 2007;2:204

42. Sendid B, Dotan N, Nseir S, Savaux C, Vandewalle P, Standaert A, Zerimech F, Guery BP, Dukler A, Colombel JF, Poulain D. Antibodies against glucan, chitin, and Saccharomyces cerevisiae mannan as new biomarkers of Candida albicans infection that complement tests based on C. albicans mannan. Clin Vaccine Immunol. 2008;15:1868-77.

43. Vasiliauskas EA, Kam LY, Karp LC, Gaiennie J, Yang H, Targan SR. Marker antibody expression stratifies Crohn's disease into immunologically homogeneous subgroups with distinct clinical characteristics. Gut. 2000;47:487-96.

44. Taylor BD, Darville T, Ferrell RE, Ness RB, Haggerty CL. Racial variation in toll-like receptor variants among women with pelvic inflammatory disease. J Infect Dis. 2013;207:940-6.

45. Gillum AM, Tsay EY, Kirsch DR. Isolation of the Candida albicans gene for orotidine-5'-phosphate decarboxylase by complementation of S. cerevisiae ura3 and E. coli pyrF mutations. Mol Gen Genet. 1984;198:179-82.

46. Rubino I, Coste A, Le Roy D, Roger T, Jaton K, Boeckh M, Monod M, Latge JP, Calandra T, Bochud PY. Species-specific recognition of Aspergillus fumigatus by toll-like receptor 1 and toll-like receptor 6 . J Infect Dis. 2012;205:944-54.

47. Edwards-Ingram L, Gitsham P, Burton N, Warhurst G, Clarke I, Hoyle D, Oliver SG, Stateva L. Genotypic and physiological characterization of Saccharomyces boulardii, the probiotic strain of Saccharomyces cerevisiae. Appl Environ Microbiol. 2007;73:2458-67.

48. Siegmund B, Rieder F, Albrich S, Wolf K, Bidlingmaier C, Firestein GS, Boyle D, Lehr HA, Loher F, Hartmann G, et al. Adenosine kinase inhibitor
GP515 improves experimental colitis in mice. J Pharmacol Exp Ther. 2001;296:99-105.

49. Bergstrom KS, Kissoon-Singh V, Gibson DL, Ma C, Montero M, Sham HP, Ryz N, Huang T, Velcich A, Finlay BB, et al. Muc2 protects against lethal infectious colitis by disassociating pathogenic and commensal bacteria from the colonic mucosa. PLoS Pathog. 2010;6:e1000902.

50. Jawhara S, Mogensen E, Maggiotto F, Fradin C, Sarazin A, Dubuquoy L, Maes E, Guerardel Y, Janbon G, Poulain D. Murine model of dextran sulfate sodium-induced colitis reveals Candida glabrata virulence and contribution of beta-mannosyltransferases. J Biol Chem. 2012;287:11313-24.

51. Saviozzi S, Cordero F, Lo lacono M, Novello S, Scagliotti GV, Calogero RA. Selection of suitable reference genes for accurate normalization of gene expression profile studies in non-small cell lung cancer. BMC Cancer. 2006;6:200.

52. Luna-Gomes T, Filardy AA, Rocha JD, Decote-Ricardo D, LaRocque-deFreitas IF, Morrot A, Bozza PT, Castro-Faria-Neto HC, DosReis GA, Nunes MP, Freire-de-Lima CG. Neutrophils increase or reduce parasite burden in Trypanosoma cruzi-infected macrophages, depending on host strain: role of neutrophil elastase. PLoS ONE. 2014;9:e90582.

53. Soloviev DA, Fonzi WA, Sentandreu R, Pluskota E, Forsyth CB, Yadav S, Plow EF. Identification of pH-regulated antigen 1 released from Candida albicans as the major ligand for leukocyte integrin aM $\beta 2$. J Immunol. 2007;178:2038-46.

54. Soloviev DA, Jawhara S, Fonzi WA. Regulation of innate immune response to Candida albicans infections by aM $\beta 2$-Pra $1 p$ interaction. Infect Immun. 2011;79:1546-58.

\section{Submit your next manuscript to BioMed Central and we will help you at every step:}

- We accept pre-submission inquiries

- Our selector tool helps you to find the most relevant journal

- We provide round the clock customer support

- Convenient online submission

- Thorough peer review

- Inclusion in PubMed and all major indexing services

- Maximum visibility for your research

Submit your manuscript at www.biomedcentral.com/submit
( BioMed Central 